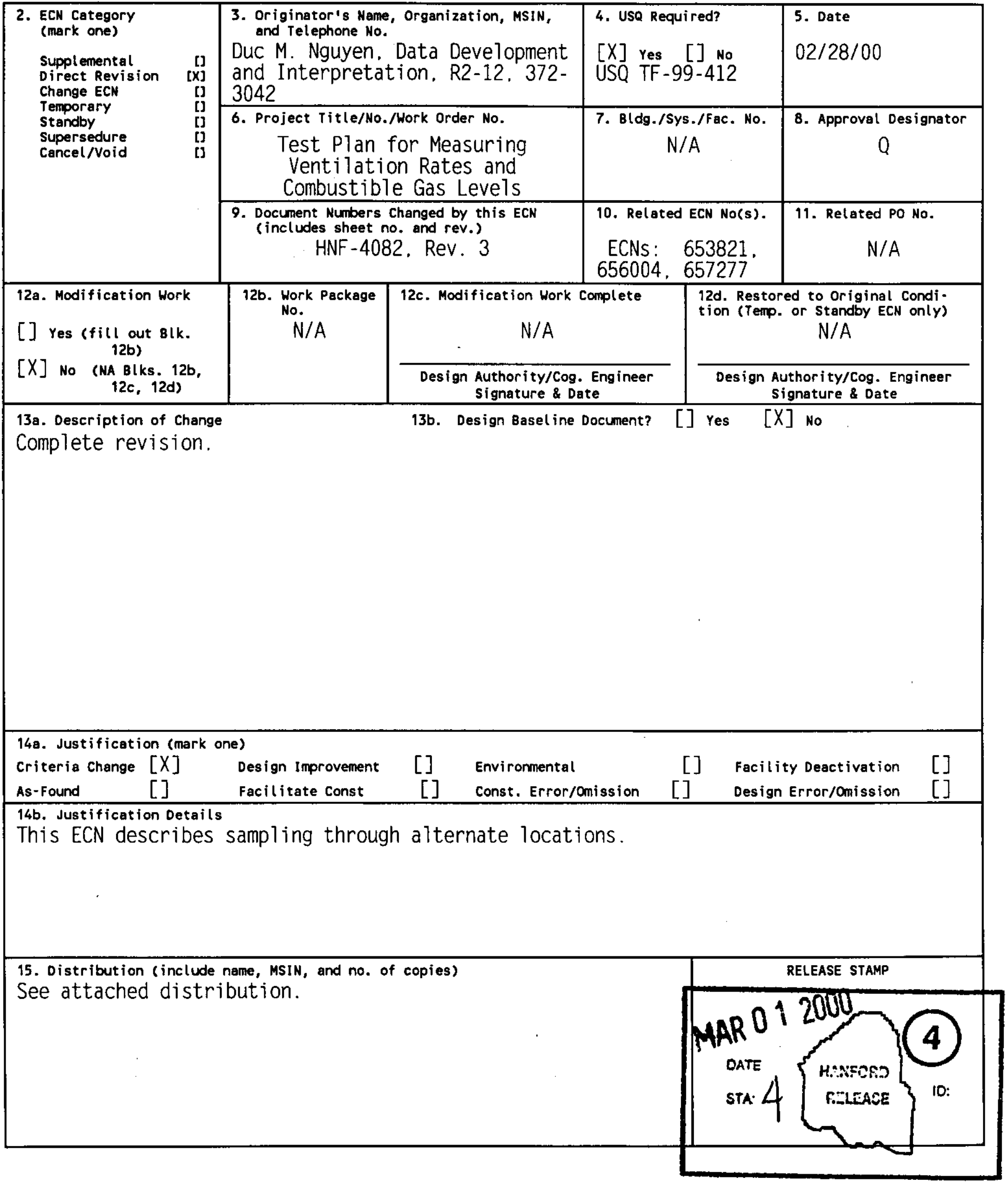




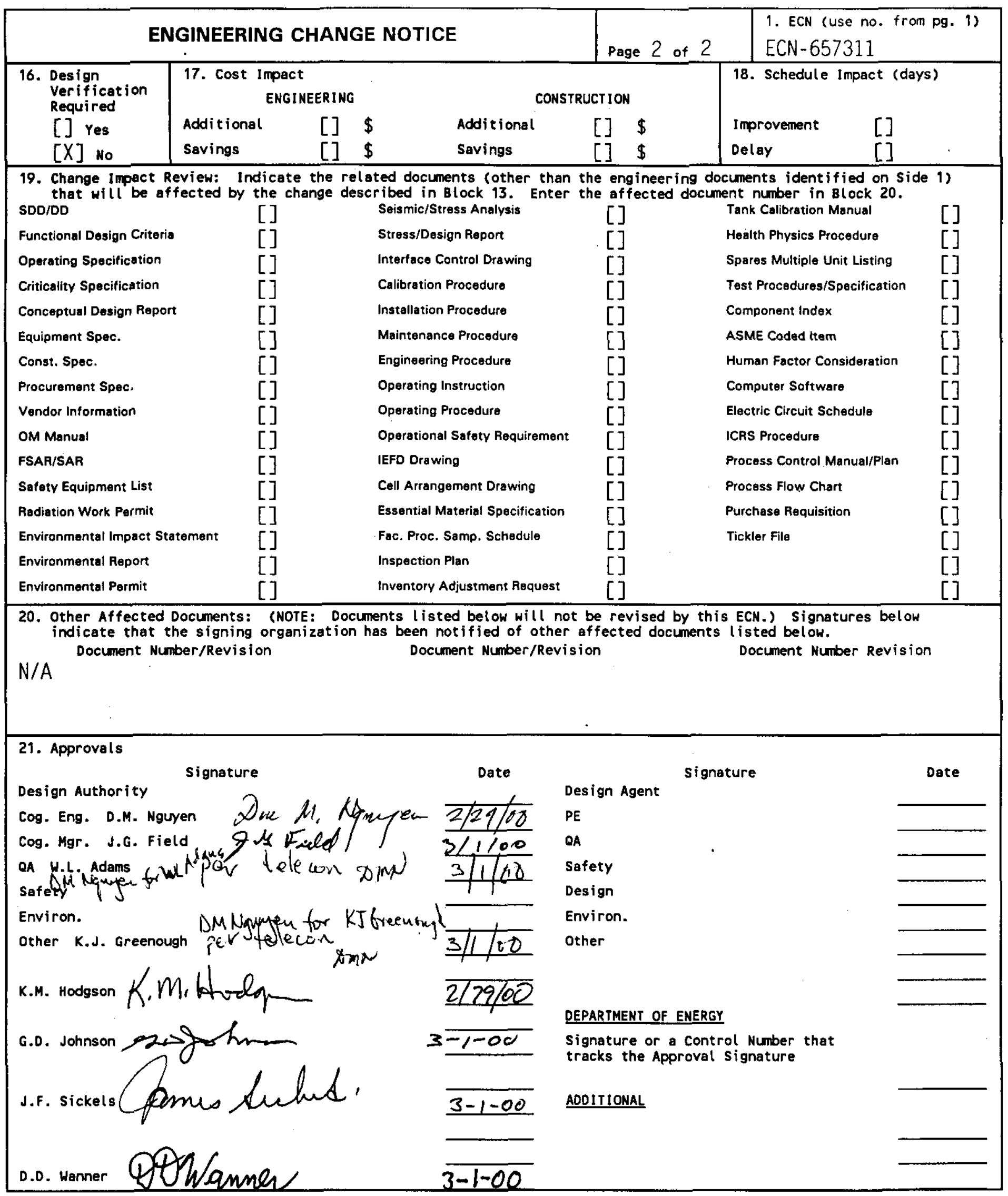




\begin{tabular}{|c|c|c|c|c|c|c|}
\hline \multicolumn{7}{|c|}{ DISTRIBUTION SHEET } \\
\hline \multirow[b]{2}{*}{ Distribution } & \multirow{2}{*}{\multicolumn{4}{|c|}{ From }} & \multicolumn{2}{|l|}{ Page 1 of 1} \\
\hline & & & & & \multicolumn{2}{|c|}{ Date $\quad 02 / 28 / 00$} \\
\hline \multirow{2}{*}{\multicolumn{5}{|c|}{$\begin{array}{l}\text { Project Title/Work Order } \\
\text { HNF-4082. Rev. 4. "Test Plan for Measuring Ventilation Rates and } \\
\text { Combustible Gas Levels in RPP Active Catch Tanks" }\end{array}$}} & \multirow{2}{*}{\multicolumn{2}{|c|}{$\begin{array}{ll}\text { EDT No. } & \text { N/A } \\
\text { ECN No. } & \text { ECN-657311 }\end{array}$}} \\
\hline & & & & & & \\
\hline \multicolumn{2}{|l|}{ Name } & MSIN & $\begin{array}{l}\text { Text } \\
\text { with } \\
\text { All } \\
\text { Attach. }\end{array}$ & Text Only & $\begin{array}{l}\text { Attach./ } \\
\text { Appendix } \\
\text { Only }\end{array}$ & $\begin{array}{l}\text { EDT/ECN } \\
\text { Only }\end{array}$ \\
\hline \multicolumn{5}{|c|}{$\begin{array}{ll}\text { CH2M HILL Hanford Group. Inc. } & \\
\text { W. L. Adams } & \text { S6-15 } \\
\text { W. B. Barton } & \text { R2-12 } \\
\text { D. A. Bragg } & \text { S5-05 } \\
\text { R. J. Cash } & \text { R1-44 } \\
\text { J. G. Field } & \text { R2-12 } \\
\text { D. J. Green } & \text { S7-90 } \\
\text { K. M. Hodgson } & \text { R2-11 } \\
\text { G. D. Johnson } & \text { R1-44 } \\
\text { P. F. Kison } & \text { T4-07 } \\
\text { R. E. Larson } & \text { T4-07 } \\
\text { D. M. Nguyen } & \text { R2-12 } \\
\text { J. F. Sickels } & \text { S7-03 } \\
\text { D. D. Wanner } & \text { S7-12 } \\
\text { T.C.S.R.C. } & \text { R1-10 }\end{array}$} & & \\
\hline \multicolumn{2}{|l|}{$\begin{array}{l}\text { Fluor Hanford } \\
\text { R. K. Fuller } \\
\text { K. J. Greenough } \\
\text { K. L. Powe11 } \\
\text { R. S. Viswanath }\end{array}$} & $\begin{array}{l}\text { T6-12 } \\
\text { S3-30 } \\
\text { T6-04 } \\
\text { S3-30 }\end{array}$ & $\begin{array}{l}x \\
x \\
x \\
x\end{array}$ & & & \\
\hline \multicolumn{2}{|l|}{$\begin{array}{l}\text { Lockheed Martin Services, Inc. } \\
\text { Central Files }\end{array}$} & B1-07 & $x$ & & & \\
\hline \multicolumn{2}{|l|}{$\frac{\text { Numatec }}{\text { W. I. Winters }}$} & T6-07 & $x$ & & & \\
\hline \multicolumn{2}{|l|}{$\begin{array}{l}\text { Office of River Protection } \\
\text { DOE Reading Room }\end{array}$} & $\mathrm{H} 2-53$ & $x$ & & & \\
\hline \multicolumn{2}{|c|}{$\begin{array}{l}\text { Pacific Northwest National Laboratory } \\
\text { S. J. Bos } \\
\text { J. W. Brothers }\end{array}$} & $\begin{array}{l}P 7-22 \\
K 9-20\end{array}$ & $\begin{array}{l}x \\
x\end{array}$ & & & \\
\hline \multicolumn{5}{|c|}{$\frac{\text { Waste Management Federal Services of Hanford, Inc. }}{\text { C. M. Seidel }}$} & & \\
\hline
\end{tabular}




\section{Test Plan for Measuring Ventilation Rates and Combustible Gas Levels in RPP Active Catch Tanks}

D. M. Nguyen

CH2M HILL Hanford Group. Inc. . Richland. WA 99352

U.S. Department of Energy Contract DE-AC06-96RL13200

EDT/ECN: ECN-657311

Org Code: $74 \mathrm{~B} 20$

UC: 2070

CACN/COA: $101922 /$ ES13

B\&R Code: EW 3120074 Total Pages: 38

Key Words: Test Plan. Measuring, Ventilation Rates, Ventilation, Combustible Gas Levels, Gas. TWRS, Active Catch Tanks. Active, Catch Tanks

Abstract: N/A

Hoke is a trademark of Hoke Incorporated, Cresski11. New Jersey

SUMMA is a trademark of Moletrics, Inc., Cleveland, Ohio

TRADEMARK DISCLAIMER. Reference herein to any specific commercial product, process, or service by trade nane, trademark, manufacturer, or otherwise, does not necessarily constitute or imply its endorsement, recommendation, or favoring by the United States Government or any agency thereof or its contractors or subcontractors.

Printed in the United States of America. To obtain copies of this document, contact: Document Control Services, P.0. BOX 950, Mailstop H6-08, Richland WA 99352, Phone (509) 372-2420;

Fax (509) 376-4989.
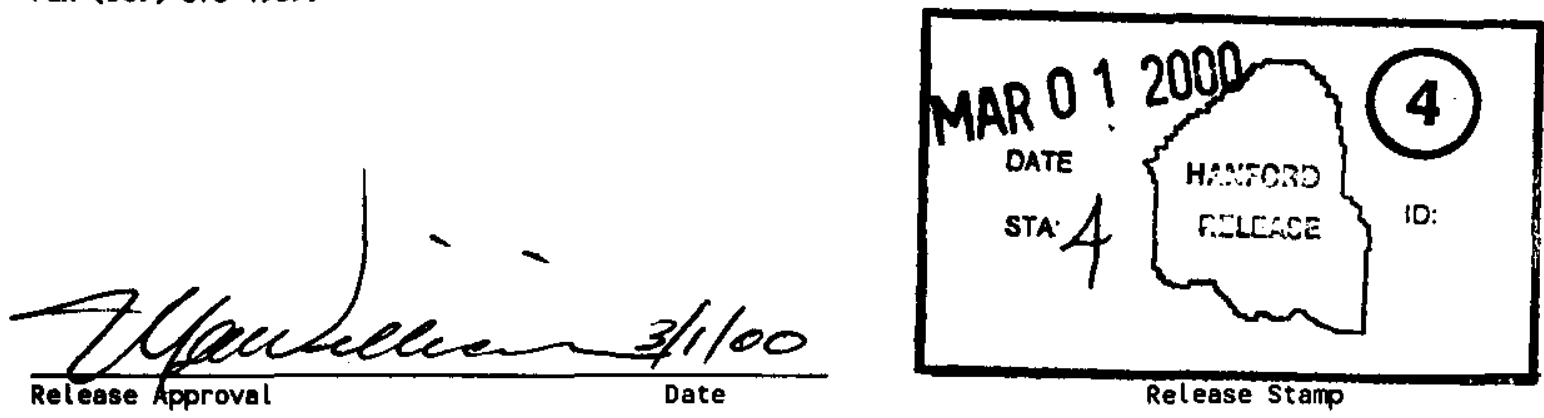

Approved for Public Release 


\section{RECORD OF REVISION}

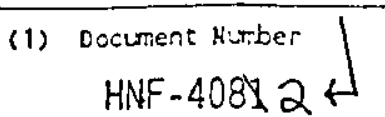

Page 1

(2) ritle

Test Plan for Measuring Ventilation Rates and Combustible Gas Levels in RPP Active Catch Tanks

\begin{tabular}{|c|c|c|c|}
\hline & CHANGE CONTROL RECORO & & \\
\hline (3) Revision & (4) Description of Change - Reptace, Add, and Delete Pages & Authori & zed for Release \\
\hline & & (5) Cog. Engr. & (6) Cog. Mgr. \\
\hline 0 & $\begin{array}{l}\text { (7) Injtially released } 03 / 15 / 99 \text { on EDT- } \\
611453 \text {. }\end{array}$ & H.B. Barton & K.M. Hodgșon \\
\hline${ }^{1} \mathrm{RS}$ & Incorporate per ECN-653821. & W.8BBarton & K.M. Hodgson \\
\hline $\mathrm{RSQ}$ & Incorporate per Ech-656004. & W. B. Darton & h.m. Hodgson ${ }^{10-2^{2}}$ \\
\hline & & & 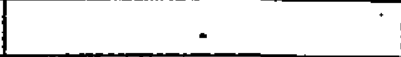 \\
\hline RS 3 & Incorporate per Ech-657277. & o.m. nguyen & J.G. Field \\
\hline & 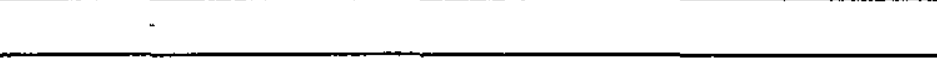 & Due M Ngayen & Af fivel \\
\hline & & 11 & $71 / 31 / 60$ \\
\hline RS4 & Incorporate per Ecn- 657311 . & D.m. nguyen & J.G. Field \\
\hline & & Son M. Moman & Sherile 3/1/00 \\
\hline & & & \\
\hline & & & \\
\hline & & & \\
\hline & & & \\
\hline & & & \\
\hline & & & \\
\hline & & & \\
\hline & & & \\
\hline & & - & \\
\hline & & & \\
\hline & & & . \\
\hline & & & \\
\hline & & & \\
\hline & & & The \\
\hline & & & \\
\hline & & & \\
\hline & & & \\
\hline & & & \\
\hline & & & \\
\hline & & & \\
\hline
\end{tabular}


HNF-4082

Revision 4

\title{
TEST PLAN FOR MEASURING VENTILATION RATES AND COMBUSTIBLE GAS LEVELS IN RPP ACTIVE CATCH TANKS
}

\author{
D. M. Nguyen \\ CH2MHILL Hanford Group, Inc.
}

Date Published

February 2000

Prepared for the U. S. Department of Energy

Assistant Secretary for Environmental Management

Project Hanford Management Contractor for the

U.S. Department of Energy under Contract DE-AC06-96RL13200

Approved for public release; distribution is unlimited 
HNF-4082 Rev. 4

This page intentionally left blank 


\section{TABLE OF CONTENTS}

1.0 PURPOSE AND SCOPE

2.0 BACKGROUND

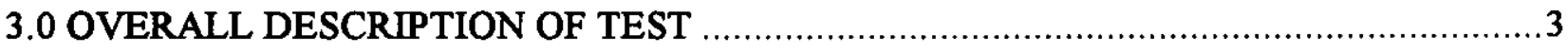

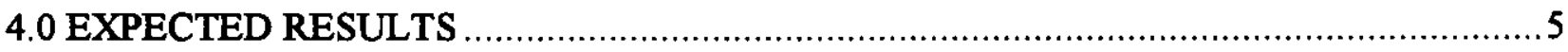

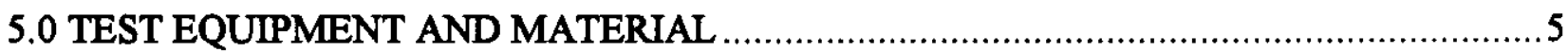

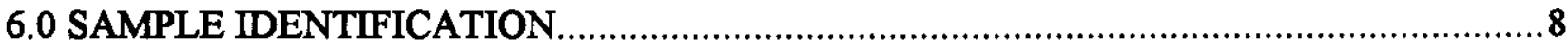

7.0 DATA REQUIREMENTS

7.1 REQUIREMENTS FOR FIELD DATA

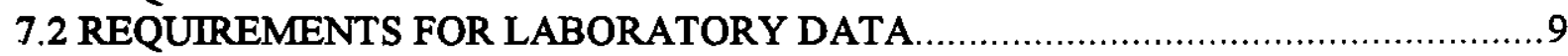

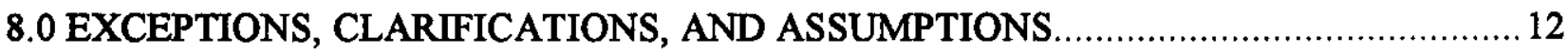

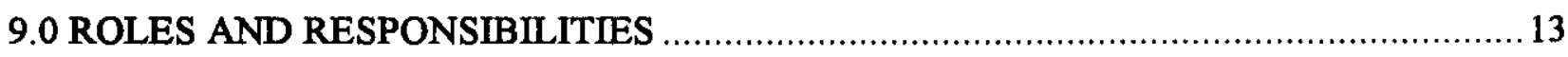

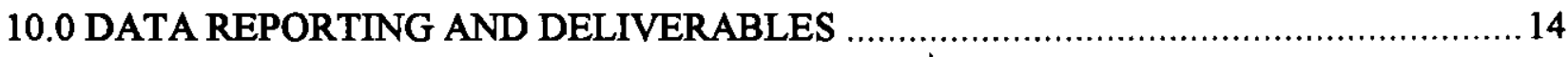

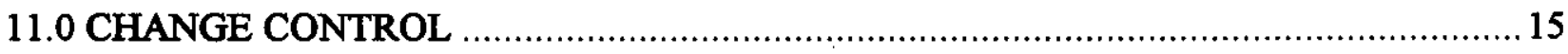

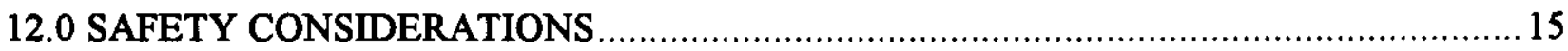

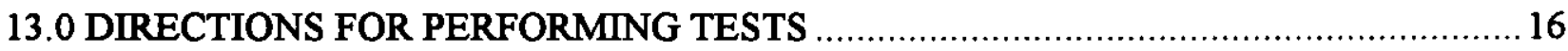

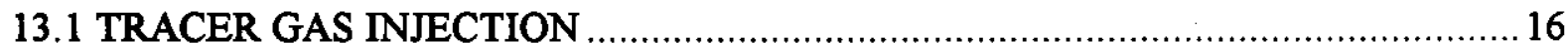

13.2 FIELD COMBUSTIBLE GAS LEVEL MEASUREMENTS …........................... 18

13.2.1 Sampling Through a Riser or Equivalent ................................................ 18

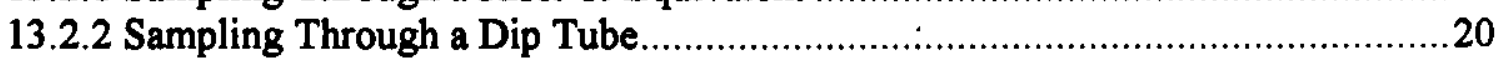

13.2.3 Sampling Through a Sampling Port (Tank 204-AR-TK-1) .............................21

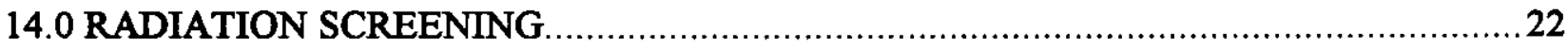

15.0 REFERENCES

\section{APPENDICES}

APPENDIX A. METHOD FOR CALCULATING VENTILATION RATE IN A CATCH

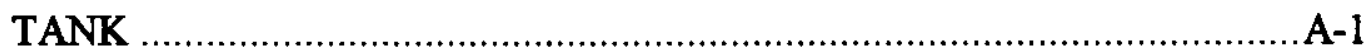

APPENDIX B. DATA SHEET FOR USE WITH TRACER GAS INJECTION ..................... B-1 


\section{LIST OF FIGURES}

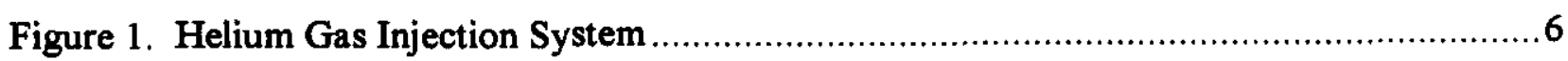

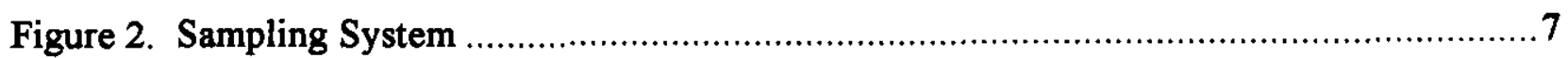

\section{LIST OF TABLES}

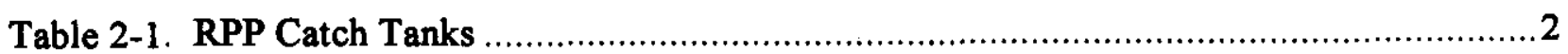

Table 3-1. Data Needs and Associated Measurement Methods ...............................................

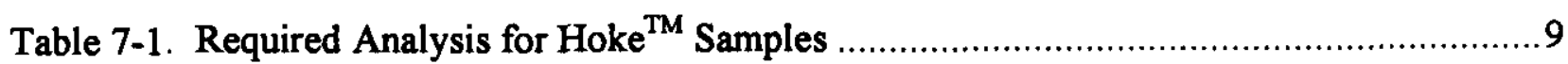

Table 7-2. Analytical Methods and Laboratory Quality Control Requirements for SUMMA ${ }^{\text {TM }}$

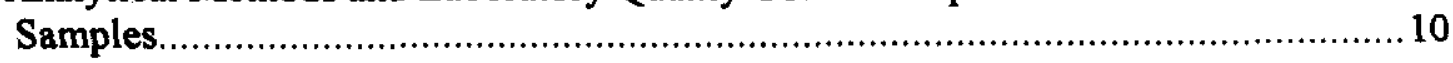

Table 9-1. Key Personnel for Sampling and Analysis of Catch Tanks ..................................13

\section{LIST OF TERMS}

CGM combustible gas monitor

CPO Characterization Project Operations

cfh cubic feet per hour

cfm cubic feet per minute

DB diversion box

gal gallon

HEPA high-efficiency particulate air (filter)

LFL lower flammability limit

OVM organic vapor monitor

ppm parts per million

$\% \quad$ percent

psig pounds per square inch gauge

RQL required quantitation limits

SAS Special Analytical Support

SOP standard operating procedure

RPP River Protection Project

USQ unreviewed safety question

WSCF Waste Sampling and Characterization Facility 
HNF-4082 Rev. 4

\section{TEST PLAN FOR MEASURING VENTILATION RATES AND COMBUSTIBLE GAS LEVELS IN RPP ACTIVE CATCH TANKS}

\subsection{PURPOSE AND SCOPE}

The purpose of this data collection activity is to obtain data for a screening of combustible gases in catch tanks that are currently operated by the River Protection Project (RPP). The results will be used to support closure of the flammable gas unreviewed safety question for these facilities. The data collection will be conducted in accordance with the Tank Safety Screening Data Quality Objective (Dukelow et al. 1995).

Combustible gas, ammonia, and organic vapor levels in the headspace of the catch tanks will be field-measured using hand-held instruments. If a combustible gas level measurement in a tank exceeds an established threshold, vapor grab samples (i.e., Hoke ${ }^{1}$ and SUMMA ${ }^{1}$ ) will be collected for laboratory analysis. In addition, ventilation rates of some catch tanks will be determine using the tracer gas injection method to evaluate removal of flammable gas by air flowing through the tanks.

This test plan identifies the field tests, sample collection, laboratory analysis, quality assurance, and reporting objectives for this data collection effort. The plan also provides step-by-step direction for field measurement of combustible gas concentrations and determination of ventilation rates.

\subsection{BACKGROUND}

In general, RPP catch tanks were designed to collect leaks, spills, condensation, and drainage that might occur during operation of tank farm diversion boxes (DBs), valve pits, and pipeline encasement. Volume and constituents of the material in these tanks vary depending on the operations of the Tank Farm facilities. Most of these tanks are expected to contain small amounts of organic chemicals and low levels of radioactivity. Thus, flammable gases could be generated and accumulated in these tanks. A list of the RPP active catch tanks is shown in Table 2-1. A description of tank capacity, material of construction, and ventilation equipment is also provided.

\footnotetext{
${ }^{1}$ Hoke and SUMMA are registered trademarks of Hoke Incorporated of Cresskill, NJ and Moletrics Inc. or Cleveland, $\mathrm{OH}$, respectively.
} 
Table 2-1. RPP Catch Tanks (2 Sheets)

\begin{tabular}{|c|c|c|c|c|c|}
\hline (1) & (y) & m.9.9.9. & 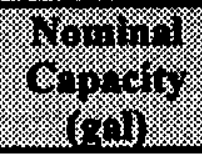 & 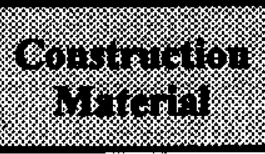 & 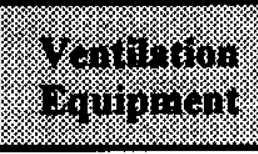 \\
\hline 1 & 241-A-302A & $\begin{array}{l}\text { Drainage from DB } \\
241-A-151\end{array}$ & $8,400 \mathrm{gal}$ & Carbon steel & None \\
\hline 2 & 241-A-350 & $\begin{array}{l}\text { Drainage from } \mathbf{A} \\
\text { Farm }\end{array}$ & $800 \mathrm{gal}$ & Stainless steel & Dip tubes ${ }^{1}$ \\
\hline 3 & 241-A-417 & $\begin{array}{l}\text { Drainage from } 241- \\
\text { AY/AZ vent }\end{array}$ & $44,000 \mathrm{gal}$ & $\begin{array}{c}\text { Concrete } \\
\text { vault with } \\
\text { carbon steel } \\
\text { liner }\end{array}$ & $\begin{array}{l}\text { Breather filter } \\
\text { and dip tubes }\end{array}$ \\
\hline 4 & 241-AX-152 & $\begin{array}{l}\text { Drainage from AX- } \\
152 \text { diversion station, } \\
\text { DB } 241-\mathrm{AX}-155 \text {, } \\
\text { AY-501, and } 702-\mathrm{A} \\
\text { seal pot }\end{array}$ & $11,000 \mathrm{gal}$ & $\begin{array}{l}\text { Concrete } \\
\text { vault with } \\
\text { steel liner }\end{array}$ & $\begin{array}{l}\text { None (Known } \\
\text { to benefit } \\
\text { indirectly } \\
\text { from } 702-\mathrm{AZ} \\
\text { vent system) }\end{array}$ \\
\hline 5 & 241-AZ-151 & $\begin{array}{l}\text { Drainage from DB } \\
241-A Z-152, A Z \\
\text { vent. Loop seals, leak } \\
\text { detection pits, } 801- \\
\text { AZ Instrumentation } \\
\text { Building and } \\
\text { precipitation/runoff }\end{array}$ & $12,000 \mathrm{gal}$ & $\begin{array}{c}\text { Concrete } \\
\text { vault with } \\
\text { carbon steel } \\
\text { liner }\end{array}$ & $\begin{array}{l}\text { Yes (may } \\
\text { benefit } \\
\text { indirectly } \\
\text { from } 702-\mathrm{AZ} \\
\text { system) }\end{array}$ \\
\hline 6 & 241-AZ-154 & $\begin{array}{l}\text { Drainage from AZ- } \\
101 \text { and } A Z-102 \\
\text { steam coils and } \\
\text { precipitation/runoff }\end{array}$ & $900 \mathrm{gal}$ & $\begin{array}{c}\text { Concrete } \\
\text { vault with } \\
\text { carbon steel } \\
\text { liner } \\
\end{array}$ & None \\
\hline 7 & 241-ER-311 & $\begin{array}{l}\text { Drainage from DBs } \\
151-E R \text { and } 152-E R \text {. }\end{array}$ & $18,000 \mathrm{gal}$ & Carbon steel & None \\
\hline 8 & 204-AR-TK-1 & $\begin{array}{l}\text { Drainage from the } \\
\text { 204-AR Waste } \\
\text { Unloading Facility } \\
\text { unloading canyon. }\end{array}$ & $1,500 \mathrm{gal}$ & Stainless steel & Exhauster \\
\hline 9 & 241-S-304 & $\begin{array}{l}\text { Drainage from DB } \\
241-S-151 \text { and } \\
\text { precipitation/runoff }\end{array}$ & $6,000 \mathrm{gal}$ & Carbon steel & Breather filter \\
\hline 10 & $241-T X-302 C$ & $\begin{array}{l}\text { Drainage from DB } \\
241-T X-154 \text { and } \\
\text { precipitation/runoff }\end{array}$ & $18,000 \mathrm{gal}$ & Carbon steel & None \\
\hline 11 & 241-U-301B & $\begin{array}{l}\text { Drainage from DBs } \\
241-\mathrm{U}-151,241-\mathrm{U}- \\
152,241-\mathrm{U}-153,241- \\
\mathrm{U}-252\end{array}$ & $36,000 \mathrm{gal}$ & $\begin{array}{l}\text { Concrete } \\
\text { (unlined) }\end{array}$ & None \\
\hline
\end{tabular}


Table 2-1. RPP Catch Tanks (2 Sheets)

\begin{tabular}{|c|c|c|c|c|c|}
\hline 10 & 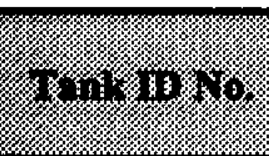 & 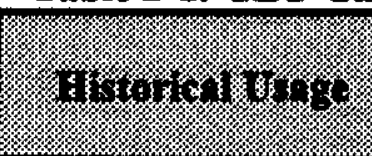 & (a) & angming & 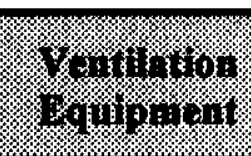 \\
\hline 12 & $241-U X-302 A$ & $\begin{array}{l}\text { Drainage from DB } \\
241-U X-154,291-U \\
\text { stack, and } \\
\text { precipitation/runoff }\end{array}$ & $18,000 \mathrm{gal}$ & Carbon steel & None \\
\hline 13 & 241-EW-151 & $\begin{array}{l}\text { Drainage from the } \\
\text { former cross-site } \\
\text { transfer vent station }\end{array}$ & $800 \mathrm{gal}$ & Carbon steel & Breather filter \\
\hline
\end{tabular}

${ }^{1}$ Dip tubes are a liquid level measurement device based on differential air pressure. Air is forced through the tubes at 20 psig. The use of dip tubes provides a small ventilation rate.

\subsection{OVERALL DESCRIPTION OF TEST}

The flammable gas content of each catch tank and the ventilation rates in two of the tanks will be measured. Gas levels will be measured in the field using portable or hand-held gas meters. Ventilation rates will be determined using the tracer gas injection method. These methods have been used successfully for waste tanks and double-container receiver tanks (Bauer 1998 and Bauer and Hedengren 1999). The gas level and ventilation rate measurement methods are specified in Table 3-1.

Table 3-1. Data Needs and Associated Measurement Methods

\begin{tabular}{|c|c|}
\hline Combustible gas level & Combustible Gas Monitor (CGM) \\
\hline Ammonia & Calorimetric (Draeger) Tubes \\
\hline Organic vapor & Organic Vapor Monitor \\
\hline Ventilation Rate & Tracer gas (Helium) injection \\
\hline
\end{tabular}

The appropriate tank access point (e.g., riser) and sample locations (i.e., depths) within the vapor space of each catch tank will be determined during the planning phase. Also, the sampling system must be purged to assure that the sample system tubing is filled only with gas from the headspace. The required duration for purging depends on the length of the system tubing. The sampling cognizant engineer shall determine the tank access point, sample locations, and the 
appropriate purging duration for each catch tank. The information shall be specified in the field work package.

Combustible gas, ammonia, and organic vapor concentrations will be measured three times at each sampling location. If a combustible (flammable) gas level measurement exceeds $25 \%$ of the LFL, Hoke ${ }^{\mathrm{TM}}$ and SUMMA ${ }^{\mathrm{TM}}$ samples will be collected for laboratory analysis. Also, for tanks with no known path for ventilation, the tank access shall be reconfigured to allow ventilation of the flammable gas instead of restoring the tank access point to the initial condition when sampling is complete (e.g., installing a flange or bag with air filter). Step-by-step directions for taking the field measurements and the grab samples are provided in Section 13.

The ventilation rates in the RPP active catch tanks are not known and are expected to vary. Seven of the thirteen tanks were installed with equipment that provides various degrees of ventilation. The equipment includes breather filters, dip tubes, and exhausters. The other tanks do not have installed ventilation equipment but some may be connected to other systems that have either active or passive ventilation. Two tanks, 241-AX-152 and 241-EW-151, have been selected for tracer gas injection to provide an indication of the range of gas removal rate due to airflow through the tanks.

Helium will be injected into the headspace of a designated tank through an assigned injection point as specified by the sampling cognizant engineer. The sampling cognizant engineer will specify the required volume of helium based on measured decrease in pressure of the gas supply. Two SUMMA ${ }^{\mathrm{TM}}$ samples will be collected after allowing the helium to disperse evenly throughout the tank headspace. One additional set of two SUMMA ${ }^{\mathrm{TM}}$ samples (and an optional third set of samples) will be collected at a time interval to be specified by the sampling cognizant engineer. These SUMMA ${ }^{\mathrm{TM}}$ samples will be analyzed for helium concentration only. Ventilation rate in the tank will be calculated based on the measured decay in helium concentration between these points in time. The calculation method is derived and described in Appendix A.

Note that the tests described in this plan will provide screening data only. A comprehensive evaluation of potential variables (i.e., factors that could affect combustible gas generation or retention in a catch tank), such as volume, composition, and temperature of the waste and atmospheric conditions, etc., are outside the scope of this effort. However, these data will be recorded if available. 


\subsection{EXPECTED RESULTS}

For each catch tank, combustible gas level (in \%LFL), ammonia concentration (in parts per million [ppm]), and organic vapor level (in ppm) will be measured and reported. The levels of these gases and vapors in the catch tanks are expected to be very low.

Tank 241-AX-152 headspace is indirectly connected to the 702-AZ ventilation system and, thus, is considered an actively ventilated tank. This tank is expected to have a much higher ventilation rate than that of the passively ventilated tank 241-EW-151.

\subsection{TEST EQUIPMENT AND MATERIAL}

Test equipment needed for each catch tank include:

- Combustible Gas Meter (CGM) for measuring combustible gas level,

- Organic Vapor Monitor (OVM) for measuring organic vapor concentration,

- Calorimetric (Draeger) tubes for measuring ammonia concentration, and

- Two Hoke ${ }^{\mathrm{TM}}$ samplers and two SUMMA ${ }^{\mathrm{TM}}$ canisters (with the necessary tritium traps and canister particulate air filters) to collect gas samples in the event the combustible gas level in a tank exceeds the established threshold.

- A bag or flange with high-efficiency particulate air (HEPA) filter for venting the tank after sampling if flammable gas concentration exceeds $25 \%$ of the LFL. The venting device is needed only for tanks with no known path for ventilation (i.e., no exhausters, breather filters, or dip tubes).

In addition, tracer gas injections for tanks 241-AX-152 and 241-EW-151 will require the following equipment:

- Tracer gas injection and sampling systems as shown in Figures 1 and 2, respectively,

- A supply of bottled helium gas,

- SUMMA ${ }^{\mathrm{TM}}$ canisters (with canister particulate air filters),

- A tritium trap for each SUMMA ${ }^{\mathrm{TM}}$ canister and canister particulate air filters for radiation screening, and

- Temperature gauges to measure ambient and helium gas bottle temperatures.

Spare equipment for contingency will be available as required by standard operating procedures (SOPs) for the instruments or as determined by the sampling cognizant engineer 
HNF-4082 Rev. 4

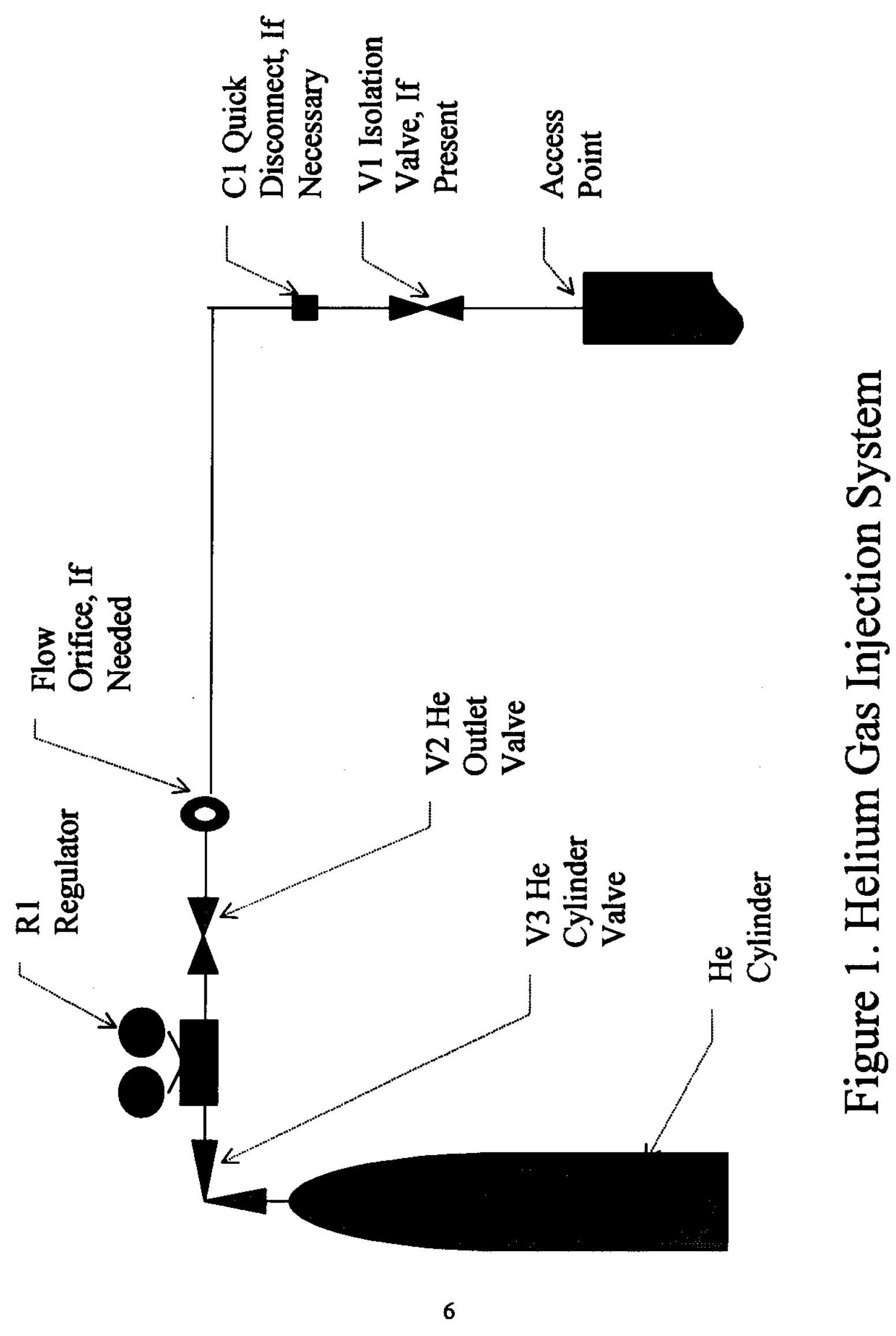


HNF-4082 Rev. 4

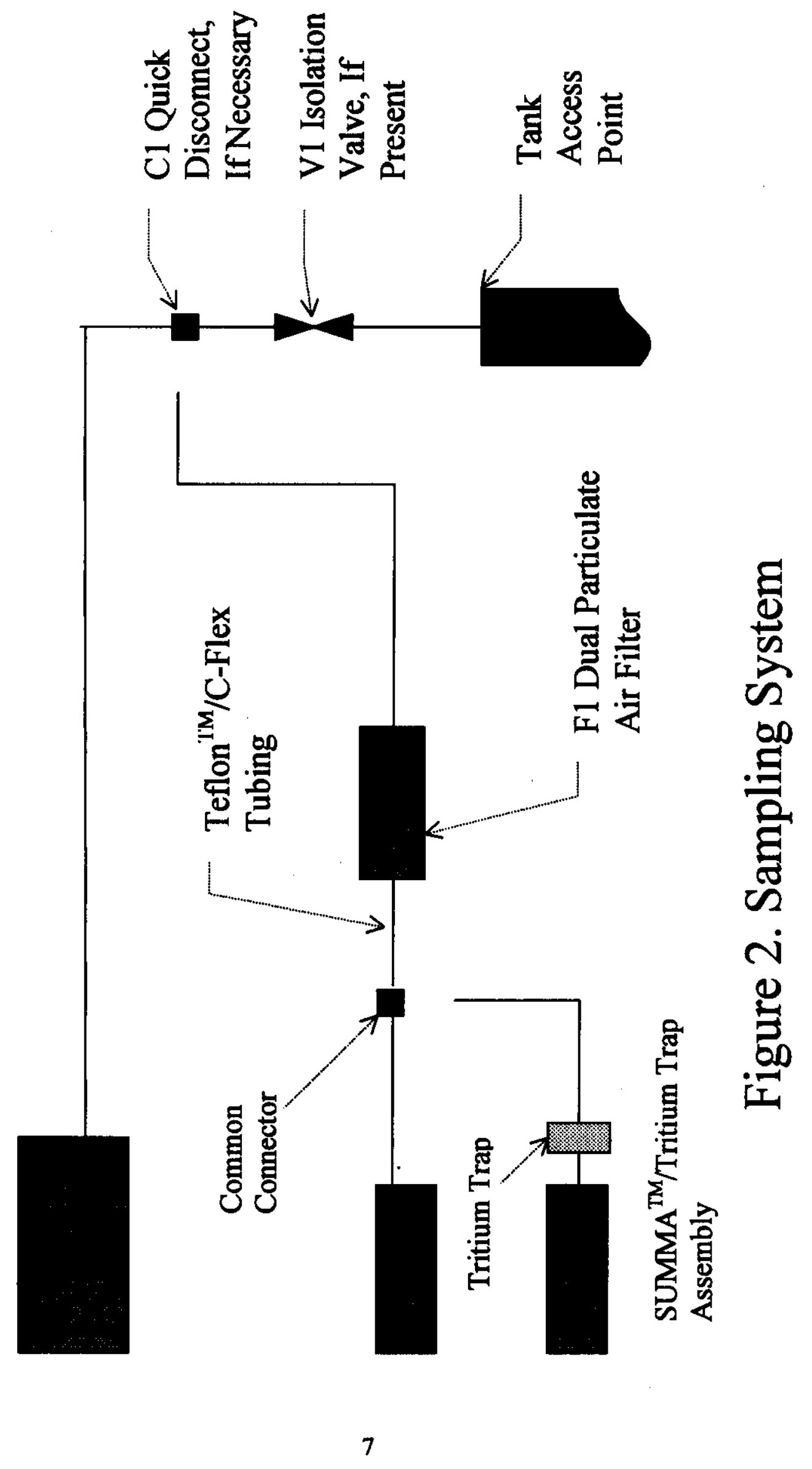




\section{HNF-4082 Rev. 4}

\subsection{SAMPLE IDENTIFICATION}

Each SUMMA ${ }^{\mathrm{TM}}$ sample will be labeled with a unique identification number. This number will also be recorded in the appropriate box on the data sheet form (see Appendix B). Each sample identification number will have the following format:

\section{VXXXXXX-YY-LLLL}

Where,

$\mathrm{V}$ indicates that the sample is a vapor sample.

XXXXXX indicates the tank number (e.g., UX302 or 0A350).

YY: a two-digit sequential number (e.g., 01, 02, or 03). For samples used for tracer gas injection, the numbers are already specified on the data sheet.

LLLL: a laboratory assigned code found on a tag attached to the SUMMA ${ }^{\mathrm{TM}}$ canister.

If used, Hoke ${ }^{\mathrm{TM}}$ samples shall be uniquely identified with the date, sequential numbers, and initials of the Industrial Hygiene and Safety (IH\&S) technician.

Characterization Project Operations (CPO) shall initiate a chain-of-custody form for each tritium trap, Hoke ${ }^{\mathrm{TM}}$ or SUMMA ${ }^{\mathrm{TM}}$ sample collected. The sample number and location (e.g., riser and elevation) at which a grab sample was obtained shall be recorded. Also, pertinent sampling information (e.g., sampling problems) should be noted in the Comments section of the chain-ofcustody form. The samples shall be shipped to the appropriate laboratory in accordance with the Job Control System (JCS) work package. 


\subsection{DATA REQUIREMENTS}

\subsection{REQUIREMENTS FOR FIELD DATA}

Test data that will be required from field operations of the tracer gas injection system are identified in the data sheet shown in Appendix B. Anomalies and environmental conditions that could affect sampling results (e.g., usual odors, machinery in operation nearby, etc.) will be noted in the Comments/Observations section of the data sheet. Other data (combustible gas level, organic vapor and ammonia concentrations) shall be recorded as directed in the work packages.

\subsection{REQUIREMENTS FOR LABORATORY DATA}

Analytical requirements for the Hoke ${ }^{\mathrm{TM}}$ samples are specified in Table 7-1. The samples will be analyzed at the Pacific Northwest National Laboratory (PNNL) according to the procedure PNNL-98523-284 (current revision) (PNNL 1999). Laboratory analysis shall be performed in accordance with the requirements in the Gas Analysis Task (Work Breakdown Structure 1.8) under the Flammable Gas Program.

\section{Table 7-1. Required Analysis for Hoke ${ }^{\mathrm{TM}}$ Samples}

\begin{tabular}{|l|l|}
\hline Carbon Monoxide & Oxygen \\
Carbon Dioxide & Methane \\
Hydrogen & Nitrogen \\
Argon & Nitrous Oxide \\
Helium & Other Nitrogen Oxides \\
& Ammonia (estimated) \\
\hline
\end{tabular}

If data from the Hoke ${ }^{\mathrm{TM}}$ sample indicate that more extensive analyses (e.g., speciation of organic vapors) are needed, the SUMMA ${ }^{\mathrm{TM}}$ sample shall be analyzed at the Waste Sampling and Characterization Facility (WSCF) for components listed in Table 7-2. Organic analysis shall be performed per analytical procedure LA-523-404. Radiation screening of particulate filters shall be performed according procedures LA-548-421 for total alpha, LA-508-415 for total beta, and LA-508-462 for gamma emitters. Tritium concentration in tritium traps shall be determined per LA-548-41 1 and LA-508-421. 
Table 7-2. Analytical Methods and Laboratory Quality Control Requirements for SUMMA ${ }^{\mathrm{TM}}$ Samples (2 Sheets)

\begin{tabular}{|c|c|c|c|c|}
\hline Amilyte & $\begin{array}{l}\text { Sworied } \\
\text { imoriod } \\
\text { Meliod }\end{array}$ & 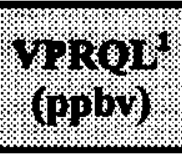 & 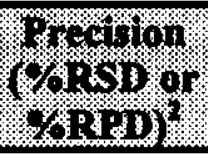 & $\begin{array}{l}\text { Alecuricy) } \\
\text { (\%) Recovery) }\end{array}$ \\
\hline Freon 12 & GC/MS ${ }^{3}$ & 5.0 & 25 & 70 to 130 \\
\hline Methyl chloride & GC/MS ${ }^{5}$ & 5.0 & 25 & 70 to 130 \\
\hline n-Butane & GC/MS ${ }^{3}$ & 5.0 & 25 & 70 to 130 \\
\hline Ethyl chloride & GC/MS ${ }^{5}$ & 5.0 & 25 & 70 to 130 \\
\hline Ethanol & GC/MS $^{5}$ & 5.0 & 25 & 70 to 130 \\
\hline Freon 11 & GC/MS ${ }^{5}$ & 5.0 & 25 & 70 to 130 \\
\hline Acetonitrile & GC/MS ${ }^{5}$ & 5.0 & 25 & 70 to 130 \\
\hline Acetone & GC/MS ${ }^{5}$ & 5.0 & 25 & 70 to 130 \\
\hline Furan & GC/MS ${ }^{5}$ & 5.0 & 25 & 70 to 130 \\
\hline n-Pentane & $\mathrm{GC} / \mathrm{MS}^{5}$ & 5.0 & 25 & 70 to 130 \\
\hline 2-Propanol & $\mathrm{GC} / \mathrm{MS}^{5}$ & 5.0 & 25 & 70 to 130 \\
\hline Dichloromethane & GC/MS ${ }^{3}$ & 5.0 & 25 & 70 to 130 \\
\hline 1-Propanol & ${\mathrm{GC} / \mathrm{MS}^{5}}$ & 5.0 & 25 & 70 to 130 \\
\hline 2-Methyl-pentane & GC/MS ${ }^{5}$ & 5.0 & 25 & 70 to 130 \\
\hline Propanenitrile & $\mathrm{GC} / \mathrm{MS}^{5}$ & 5.0 & 25 & 70 to 130 \\
\hline Butanal & GC/MS ${ }^{5}$ & 5.0 & 25 & 70 to 130 \\
\hline 1-Hexene & GC/MS ${ }^{5}$ & 5.0 & 25 & 70 to 130 \\
\hline 2-Butanone & GC/MS ${ }^{5}$ & 5.0 & 25 & 70 to 130 \\
\hline n-Hexane & $\mathrm{GC} / \mathrm{MS}^{3}$ & 5.0 & 25 & 70 to 130 \\
\hline Chloroform & $\mathrm{GC} / \mathbf{M S}^{5}$ & 5.0 & 25 & 70 to 130 \\
\hline Tetrahydrofuran & GC/MS ${ }^{3}$ & 5.0 & 25 & 70 to 130 \\
\hline 1-Butanol & $\mathrm{GC} / \mathrm{MS}^{5}$ & 5.0 & 25 & 70 to 130 \\
\hline Benzene & GC/MS & 5.0 & 25 & 70 to 130 \\
\hline Carbon tetrachloride & GC/MS ${ }^{5}$ & 5.0 & 25 & 70 to 130 \\
\hline Butanenitrile & GC/MS ${ }^{5}$ & 5.0 & 25 & 70 to 130 \\
\hline 3-Methyl-hexane & $\mathrm{GC} / \mathrm{MS}^{5}$ & 5.0 & 25 & 70 to 130 \\
\hline 2-Pentanone & GC/MS ${ }^{3}$ & 5.0 & 25 & 70 to 130 \\
\hline n-Heptane & $\mathrm{GC} / \mathrm{MS}^{3}$ & 5.0 & 25 & 70 to 130 \\
\hline 1,4-Dioxane & GC/MS ${ }^{3}$ & 5.0 & 25 & 70 to 130 \\
\hline 4-Methyl-2-pentanone & $\mathrm{GC} / \mathrm{MS}^{5}$ & 5.0 & 25 & 70 to 130 \\
\hline Toluene & GC/MS ${ }^{5}$ & 5.0 & 25 & 70 to 130 \\
\hline 2-Hexanone & GC/MS ${ }^{3}$ & 5.0 & 25 & 70 to 130 \\
\hline n-Octane & GC/MS ${ }^{5}$ & 5.0 & 25 & 70 to 130 \\
\hline Tetrachloroethylene & GC/MS ${ }^{3}$ & 5.0 & 25 & 70 to 130 \\
\hline Chlorobenzene & $\mathrm{GC} / \mathrm{MS}^{3}$ & 5.0 & 25 & 70 to 130 \\
\hline Ethylbenzene & $\mathrm{GC} / \mathbf{M S}^{3}$ & 5.0 & 25 & 70 to 130 \\
\hline $\mathrm{m}, \mathrm{p}$-Xylene & $\mathrm{GC} / \mathrm{MS}^{3}$ & 5.0 & 25 & 70 to 130 \\
\hline 3-Heptanone & $\mathrm{GC} / \mathrm{MS}^{5}$ & 5.0 & 25 & 70 to 130 \\
\hline 2-Heptanone & GC/MS ${ }^{3}$ & 5.0 & 25 & 70 to 130 \\
\hline
\end{tabular}


HNF-4082 Rev. 4

Table 7-2. Analytical Methods and Laboratory Quality Control Requirements for SUMMA ${ }^{\text {TM }}$ Samples (2 Sheets)

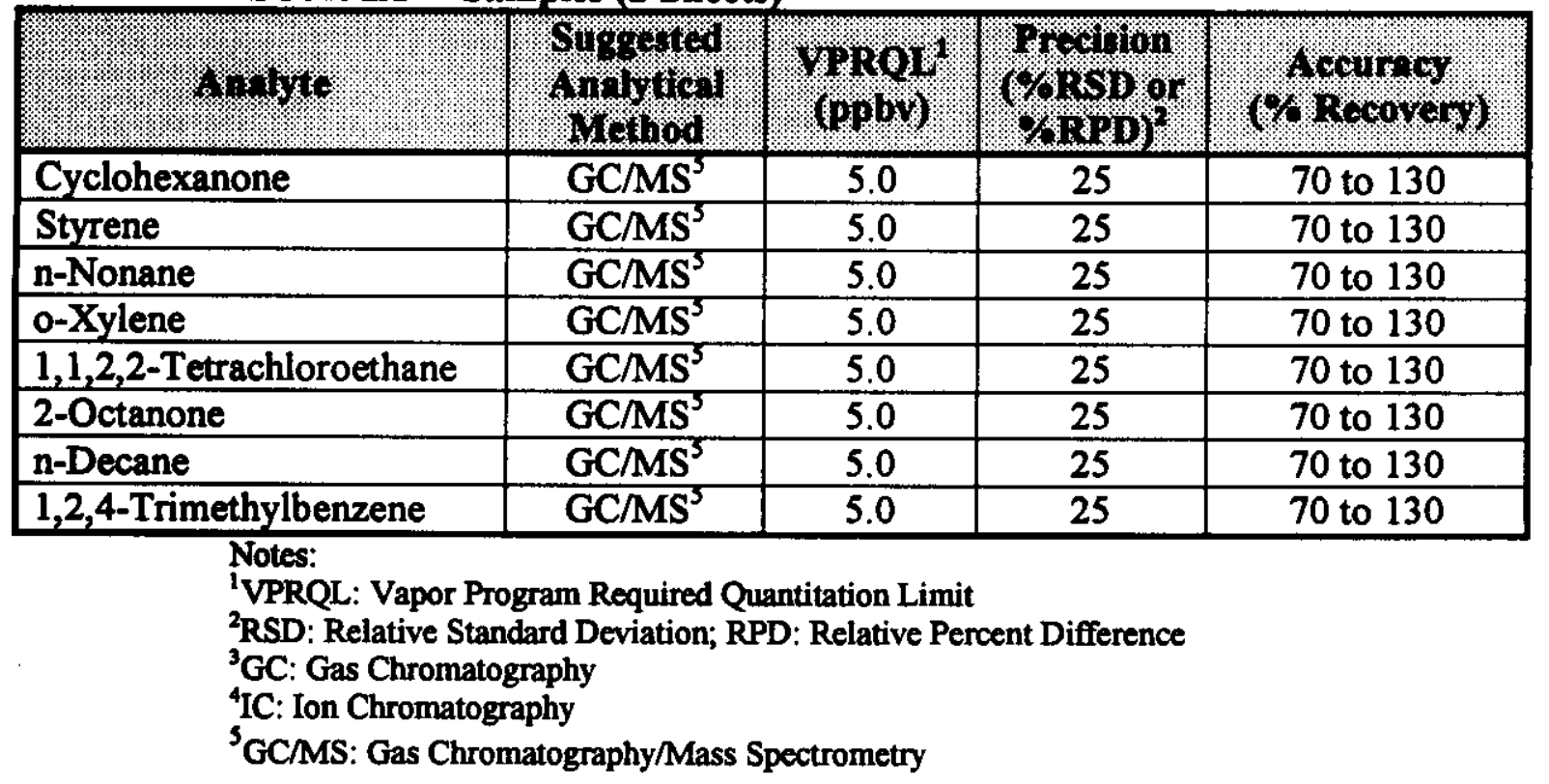

All sampling and analysis activities shall be performed in accordance with the QAVQC requirements specified in this test plan. Data resulting from activities and conditions that do not conform to requirements specified in this test plan or references herein shall be controlled to prevent inadvertent use or flagged with appropriate cautions. Nonconforming sampling and analysis processes and information shall be identified, controlled, reported, and dispositioned as required by Nonconforming Item Reporting and Control (CHG 1999).

Laboratories performing analyses in support of this SAP shall have approved and implemented quality assurance project plans. These QA plans shall meet the Hanford Analytical Services Quality Assurance Requirements Document (DOE 1998) minimum requirements for laboratory quality systems. The PNNL QA Program for Conducting Analytical Work in Support of Regulatory Programs (PNNL 1999) and the Waste Sampling and Characterization Facility Quality Assurance Program Plan (Meznarich 1999) specify the requirements for assuring the quality of sample analysis at PNNL and WSCF, respectively.

Quality control requirements shall be consistent with the specified analytical procedures and QA plans. The laboratories shall use calibration and calibration check standards appropriate for the analytical instrumentation being used (see DOE 1998 for definitions of QC samples and standards). The criteria presented are goals for demonstrating reliable method performance. It is understood that the laboratories will follow established internal protocols for addressing QC failures. If sample QC failures occur or if some analyses cannot be performed (e.g., because of insufficient sample or of matrix interference), analysts shall consult with RPP Process Engineering to determine the proper action. The performing laboratory should provide a suggested course of action at that time. All sample QC failures and limitations on the associated data shall be discussed in the narrative of the data report. Proper notification of all data not meeting $Q C$ requirements shall be included with the data. 


\subsection{EXCEPTIONS, CLARIFICATIONS, AND ASSUMPTIONS}

The Tank Safety Screening Data Quality Objective (DQO) addresses three potential safety issues: ferrocyanide and organics, criticality, and flammable gas. Only the flammable gas objectives are applicable to this data collection activity.

A combustible gas meter will be used to measure the flammable gas level in the headspace of a catch tank. The CGM will be calibrated using pentane gas. Actual CGM readings will be adjusted to percent LFL of hydrogen using a pentane-to-hydrogen conversion value recommended by the manufacturer. The assumption in the conversion is that the combustibility of the headspace vapor is due only to hydrogen. However, the presence of other combustible gases and vapors such as ammonia and organics could affect the results. Testing has shown that the CGM readings are conservative for gas mixtures (i.e., the instrument reports a higher percent LFL than that actually present for the gas mixtures tested) (Wilkins and Bauer 1996). Even so, it is desirable to determine whether or not the reported gas levels are due mainly to hydrogen or some other gases. Thus, ammonia and organic vapor concentrations will also be measured.

The main factors that could affect the concentration of combustible gas in a catch tank include the characteristics of the waste contents and the ventilation rate. These factors respectively represent the generation and removal of the gas from the tank headspace. Characteristics of the waste in the catch tanks will be examined in another activity that is outside the scope of this plan. Ventilation rate determines how fast combustible gas is removed from a tank by airflow through the headspace. Because most of the catch tanks are passively ventilated, the rate of gas removal varies according to ambient (atmospheric) conditions. Since ambient conditions change constantly, a number of measurements would be needed to accurately estimate the ventilation rates of individual catch tanks.

For the initial evaluation of combustible gas hazards in the catch tanks, only a rough indication of the range of ventilation rates is needed. Two tanks, one with active and another with passive ventilation, are selected for ventilation rate measurements. The ventilation rates in these tanks represent the approximate upper and lower bounds of the interested range. A known amount of helium gas will be injected into a tank headspace. Samples of headspace gas will be taken at measured time intervals. The ventilation rates of these tanks will be calculated based on the measured decrease in helium concentration between these points in time.

The DQO specifies that comparisons with the threshold value (i. e., $25 \%$ LFL) be made using one-sided $95 \%$ confidence level. Based on this requirement, the minimum number of needed measurements can be calculated if the mean concentration and the associated variance (a measure of the spatial variability of combustible gas in the headspace) are known. However, historical data are not available to estimate the mean percent LFL and the associated variance. Three measurements of combustible gas level in a tank are specified to support the initial hazard analysis. This number of measurements is adequate for the statistical analysis of the data and provides a contingency in the event one of the measurements must be discarded. Ammonia and organic concentrations will be measured each time a combustible gas level reading is taken (unless the 25\% LFL threshold is exceeded). 
Additional measurements may be needed to demonstrate that the combustible gas level in a catch tank is below the threshold at the $95 \%$ upper confidence level. However, it is expected that the combustible gas levels in the catch tanks are significantly below the threshold and that the spatial variability of combustible gas in a tank headspace is small. The required number of samples that is calculated based on a large difference between the mean concentration and the threshold and on a small data variance would be very small. Thus, three measurements are likely to be sufficient for the comparison.

The DQO states that "if combustible gas meter analysis results in $>10 \%$ LFL, then a Type 3 or Type 4 vapor sample must be taken and analyzed to address the flammability issue." Type 3 and Type 4 vapor samplers are not available at this time and the $>10 \%$ LFL criteria is considered too conservative. For this data collection activity, if a combustible gas meter reading exceeds $25 \%$ LFL, Hoke ${ }^{\mathrm{TM}}$ and SUMMA ${ }^{\mathrm{TM}}$ samples will be collected and analyzed. This level is consistent with the flammable gas limit established in the Tank Waste Remediation System Technical Safety Requirements (LMHC 1999).

\subsection{ROLES AND RESPONSIBHITIES}

The organization and responsibility of key personnel involved in this data collection activity are shown in Table 9-1.

Table 9-1. Key Personnel for Sampling and Analysis of Catch Tanks

\begin{tabular}{|c|c|c|}
\hline 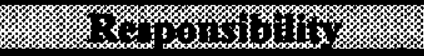 & 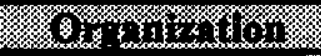 & 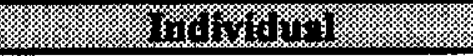 \\
\hline $\begin{array}{l}\text { Manager, Inventory } \\
\text { Control and Modeling }\end{array}$ & $\begin{array}{l}\text { RPP Process } \\
\text { Engineering }\end{array}$ & K. M. Hodgson, 373-3513 \\
\hline $\begin{array}{l}\text { Technical Lead for } \\
\text { Catch Tank Vapor } \\
\text { Sampling }\end{array}$ & $\begin{array}{l}\text { RPP Process } \\
\text { Engineering }\end{array}$ & $\begin{array}{l}\text { D. M. Nguyen, 372-3042 } \\
\text { (fax: } 373-4641 \text { ) }\end{array}$ \\
\hline $\begin{array}{l}\text { Field Sampling } \\
\text { Cognizant Engineer }\end{array}$ & $\begin{array}{l}\text { Characterization } \\
\text { Field Engineering }\end{array}$ & D. D. Wanner, 373-3297 \\
\hline \multirow[t]{2}{*}{ Laboratory Analysis } & WSCF & K. L. Powell, 372-3909 \\
\hline & PNNL & J. W. Brothers, 375-2396 \\
\hline Field Sampling & $\begin{array}{l}\text { Characterization } \\
\text { Project } \\
\text { Operations }\end{array}$ & J. F. Sickels, 373-0259 \\
\hline $\begin{array}{l}\text { Safety Issue Resolution } \\
\text { point of contact }\end{array}$ & $\begin{array}{l}\text { Safety Issue } \\
\text { Resolution }\end{array}$ & G. D. Johnson, 373-1324 \\
\hline $\begin{array}{l}\text { On-Call Process } \\
\text { Engineer }\end{array}$ & $\begin{array}{l}\text { RPP Process } \\
\text { Engineer }\end{array}$ & $\begin{array}{l}\text { On-Call Process Engineer, } \\
\text { Pager: } 85-9654\end{array}$ \\
\hline $\begin{array}{l}\text { Tank Farms point of } \\
\text { contact }\end{array}$ & $\begin{array}{l}\text { Tank Farm } \\
\text { Operations }\end{array}$ & $\begin{array}{l}\text { Double-Shell Tank Farm } \\
\text { Operations shift manager, } \\
373-2689\end{array}$ \\
\hline
\end{tabular}




\subsection{DATA REPORTING AND DELIVERABLES}

If a CGM reading exceeds $25 \%$ of the LFL, CPO shall immediately notify, via telephone, the Tank Farm Operations shift manager and/or the on-call process engineer. CPO shall provide electronic notification to the Tank Farm Operations shift manager, the Inventory Control and Modeling Manager, the technical lead for catch tank vapor sampling, and the Safety Issue Resolution point-of-contact as soon as practical. At a minimum, the electronic notification shall include the following information:

- The measured flammable gas concentration (in \%LFL);

- The identification of the catch tank;

- The location of the measurements (e.g., riser and elevation);

- The final configurations of the tank access point (e.g., whether or not a bag or flange with HEPA-type filter was installed).

Hard copies of all field measurements shall be forwarded to the catch tank sampling technical lead within one week whether or not flammable gas concentration exceeds $25 \%$ of the LFL.

The analytical laboratory for Hoke ${ }^{\mathrm{TM}}$ samples shall provide preliminary data via electronic mail to the technical lead for catch tank vapor sampling within two working days after the samples are received at the laboratory unless otherwise requested. Final reviewed data shall be transmitted formally within two weeks of receiving the sample(s). The final report shall contain the following information at a minimum:

- Sample identification,

- All analytical results,

- Estimate of analytical precision, and

- The analytical procedure used.

The analytical laboratory for SUMMA ${ }^{\mathrm{TM}}$ samples shall provide preliminary data via electronic mail to the technical lead for catch tank vapor sampling within 3 weeks after the samples are received at the laboratory. The final data package shall be completed within 10 weeks after sample receipt. The final report shall contain the following information at a minimum:

- Sample identification,

- A brief discussion of the sample preparation, analysis, and quality assurance/quality control measures,

- Concentrations of target analytes for each sample,

- Quality control data to document achieved precision and accuracy,

- Appropriate required quantitation limit (RQL) if analyte is not detected, and 
- Discussion of applicable analytical issues or data anomaly, resolution of each issue/anomaly and the impact on the data.

Catch tank vapor sampling and analytical results shall be entered into the Tank Vapor Database (TVD). CGM results shall be entered from field documents. Each data report/package for a Hoke $^{\mathrm{TM}}$ or a SUMMA ${ }^{\mathrm{TM}}$ sample shall be accompanied by an electronic version. The electronic version shall be in the standard electronic format specified in Bobrowski and Simonen (1999). The data shall be entered into the TVD and be available for viewing within 14 days after the data is received by RPP Process Engineering.

\subsection{CHANGE CONTROL}

All significant changes to the sampling, analysis, or QA/QC requirements in this SAP shall be documented by RPP Process Engineering in an engineering change notice or a letter. All such changes shall be clearly documented in the final data report. Minor changes may be documented by placing a notation in the appropriate permanent record (e.g., memorandum to file). The determination whether or not a change is significant shall be made by the technical lead for catch tank vapor sampling.

\subsection{SAFETY CONSIDERATIONS}

Pressurized helium in steel bottles will be used for the tracer gas injection. Proper precautions will be taken when handling pressurized gas bottles. The catch tanks may contain hazardous vapor and radionuclides. A survey for hazardous vapor will be performed prior to gaining access to a tank. Also, radiation and hazardous vapor will be monitored during the test as necessary. 


\section{HNF-4082 Rev. 4}

\subsection{DIRECTIONS FOR PERFORMING TESTS}

\subsection{TRACER GAS INJECTION}

Note: For catch tanks 241-AX-152 and 241-EW-151, the combustible gas level measurements (See Section 13.2) must be completed prior to performing tracer gas injection. If combustible gas level in the tank riser or headspace exceeds $25 \%$ of the LFL, the need for tracer gas injection for the tank will be re-evaluated by engineering.

\section{Direction for Performing Helium Injection (Refer to Figure 1):}

A1. Verify that the gas cylinder contains helium at pressure $<800 \mathrm{psig}$.

A2. Connect a single ended, shut-off, quick disconnect body (e.g., Swagelok part \#QC4), if necessary, to the assigned attachment point for the sample.

A3. Connect the helium injection system to the assigned tank access point at connection $\mathrm{Cl}$, if present, as directed by the work package.

A4. Verify that the helium outlet valve is closed.

A5. Measure the helium cylinder starting pressure by opening the helium cylinder valve (V3), and adjust the pressure regulator as specified in the work package.

A6. Record the starting helium cylinder starting pressure as indicated by the pressure regulator digital high-pressure stage gauge.

A7. Measure and record the helium cylinder temperature.

A8. Open the assigned sample line isolation valve (V1), if present.

A9. Begin tracer gas injection by opening the helium outlet valve (V2).

A10. Observe the bottle pressure as indicated by the digital high-pressure stage gauge on the pressure regulator. When the pressure reaches the stopping pressure as specified in the work package, stop helium flow by closing the helium outlet valve (V2).

A11. Close the assigned sample line isolation valve (V1), if present.

A12. Verify that the helium outlet valve (V2) is closed.

A13. Measure the helium cylinder final pressure using the digital high-pressure stage gauge; record the helium cylinder final pressure. 


\section{HNF-4082 Rev. 4}

A14. Close the helium cylinder valve (V3).

A15. Disconnect the helium injection system as directed by the field work package.

\section{Direction for Collecting the First Set of SUMMA ${ }^{\text {TM }}$ Samples for Gas Injection (Refer to Figure 2):}

A16. Verify that the specified time interval has elapsed since completion of the helium injection.

A17. Connect (in series) two particulate air filters to the sample line as shown in Figure 2. The particulate air filters (F1) shall be closest to the tank access point.

A18. Place a short piece of Teflon ${ }^{\mathrm{TM}}$ (or c-flex) tubing down stream of the dual particulate air filter (F1).

A19. Connect the CGM/OVM to the Teflon ${ }^{\mathrm{TM}}$ (or c-flex) tubing.

A20. Open the sample line isolation valve (V1), if present.

A21. Purge the sample line using the CGM/OVM for the duration specified in the field work package.

A22. Close the isolation valve (V1), if present.

A23. Disconnect the CGM/OVM from the Teflon ${ }^{\mathrm{TM}}$ (or c-flex) tubing.

A24. Connect the SUMMA ${ }^{\mathrm{TM}}$ tritium trap assembly.

A25. Open the isolation valve (V1), if present.

A26. Collect the first SUMMA'M sample per field work package and record the data required on the data sheet.

A27. Close the isolation valve (V1), if present.

A28. Disconnect the SUMMA ${ }^{\mathrm{TM}} /$ tritium trap assembly from the Teflon ${ }^{\mathrm{TM}}$ (or c-flex) tubing.

A29. Repeat Steps A24 through A28 to collect the second SUMMATM sample.

A30. Configure the assigned tank access point to the condition specified in the fieldwork package. 
HNF-4082 Rev. 4

Direction for Collecting the Second Set of SUMMA'TM Samples for Gas Injection (Refer to Figure 2):

A31. Verify that the specified time interval has elapsed since completing collection of the first set of SUMMA ${ }^{\mathrm{TM}}$ samples.

A32. Repeat Steps A17 through A30 to collect the second set of SUMMA ${ }^{\text {TM }}$ samples.

Direction for Collecting the Optional Third Set of SUMMA'M Samples for Gas Injection (Refer to Figure 2):

A33. Verify that the specified time interval has elapsed since completing collection of the second set of SUMMA ${ }^{\mathrm{TM}}$ samples.

A34. Repeat Steps A17 through A30 to collect the optional third set of SUMMATM samples.

\subsection{FIELD COMBUSTIBLE GAS LEVEL MEASUREMENTS}

Combustible gases in the headspace of a catch tank will be accessed by (1) inserting a sampling tube into the headspace through a riser or drain pipe, (2) connecting the sampling equipment (CGM/OVM/Draeger Tube) to a small diameter tube (e.g., a dip tube) that enters the headspace of the tank, or (3) connecting to an existing sampling port. The directions for sampling through the different types of access are provided in the following three sections.

\subsubsection{Sampling Through a Riser or Equivalent}

Three measurements of flammable gas, ammonia, and organic vapor concentrations shall be obtained at each sampling location according to the following steps:

Note: At any time during sampling, if a combustible (flammable) gas level measurement taken from within the riser exceeds $25 \%$ of the $L F L$, disregard ammonia and organic vapor sampling and proceed with Steps C1 through C12. If the measurement is from within the tank headspace, proceed with Steps DI through D8. Also, instead of restoring the tank access point to the initial condition when sampling is complete, the tank access shall be reconfigured to allow ventilation of the flammable gas (e.g., installing a flange or bag with HEPA-type filter) if the tank has no known ventilation paths (i.e., no exhauster, breather filter, or active dip tubes).

B1. Lower the sampling line approximately 1 foot into the selected riser.

B2. Purge the sample line with gas in the riser using the CGM for the duration specified in the work package. 


\section{HNF-4082 Rev. 4}

B3. Measure the concentrations of combustible gas, ammonia, and organic vapor. Record the data as directed in the work package.

B4. If flammable gas concentration in the riser is greater than $25 \%$ of the LFL, disregard ammonia and organic vapor sampling and perform Steps C1 through C12.

B5. Repeat Steps B3 and B4 twice.

B6. Lower the sampling line into the tank headspace to the depth specified in the work package.

B7. Purge the sample line with gas in the tank headspace using the CGM for the duration specified in the work package.

B8. Measure the concentrations of combustible gas, ammonia, and organic vapor. Record the data.

B9. If flammable gas concentration in the tank headspace is greater than $25 \%$ of the LFL, disregard ammonia and organic vapor sampling and perform Steps D1 through D8.

B10. Repeat Steps B8 and B9 twice.

B11. Configure the assigned tank access point to the condition as specified in the work package.

If the flammable gas level in the access riser as measured by a CGM exceeds $25 \%$ of the LFL, then perform the following steps:

C1. Connect a Hoke ${ }^{\mathrm{TM}}$ sampler to the sampling line.

C2. Purge the line through the Hoke ${ }^{\mathrm{TM}}$ sampler for the duration specified in the work package.

C3. Obtain a Hoke ${ }^{\mathrm{TM}}$ sample.

C4. Install particulate air filter(s) on the sample line.

C5. Purge the sample line for the duration specified in the field work package.

C6. Connect a SUMMA ${ }^{\mathrm{TM}} /$ tritium trap assembly to the sample line and obtain a SUMMA ${ }^{\mathrm{TM}}$ sample.

C7. Disconnect the SUMMA ${ }^{\mathrm{TM}}$ /tritium trap assembly and the particulate air filter from the sample line.

C8. Lower the sample line into the tank headspace to the depth specified in the work package. 


\section{HNF-4082 Rev. 4}

C9. Purge the sample line.

C10. Measure the concentration of combustible gas using the CGM and record the data.

C11. Repeat Steps C1 through C7.

C12. If the tank has no known ventilation paths and if it is necessary to leave the open riser unattended, install a flange or bag with HEPA-type filter over the tank access point. Otherwise, the tank access shall be reconfigured as directed by engineering.

If the flammable gas concentration in the tank headspace exceeds $25 \%$ of the LFL, then perform the following steps:

D1. Connect a Hoke ${ }^{\mathrm{TM}}$ sampler to the sampling line.

D2. Purge the line through the Hoke ${ }^{\mathrm{TM}}$ sampler for the duration specified in the field work package.

D3. Obtain a Hoke ${ }^{\mathrm{TM}}$ sample.

D4. Install particulate air filter(s) on the sample line.

D5. Purge the sample line.

D6. Connect a SUMMA ${ }^{\mathrm{TM}} /$ tritium trap assembly to the sample line and obtain a SUMMA ${ }^{\mathrm{TM}}$ sample.

D7. Disconnect the SUMMA ${ }^{\mathrm{TM}} /$ tritium trap assembly and the particulate air filter from the sample line.

D8. If the tank has no known ventilation paths and if it is necessary to leave the open riser unattended, install a flange or bag with HEPA-type filter over the tank access point. Otherwise, the tank access shall be reconfigured as directed by engineering.

\subsubsection{Sampling Through a Dip Tube}

Dip tubes are small in diameter and therefore can be effectively purged with headspace gas using a CGM. In general, three dip tubes in operation are purged with compressed air at a total of approximately 3 cubic feet per hour (cth). Thus, installation of a small, temporary HEPA-type filter if combustible gas level exceeds $25 \%$ of the LFL would not be necessary. The direction for sampling through a dip tube is provided in Steps E1 through E6.

E1. Connect the sampling instrument to the designated dip tube as directed in the work package. 


\section{HNF-4082 Rev. 4}

E2. Purge the dip tube with headspace gas using the CGM for the duration specified in the work package.

E3. Measure the concentrations of combustible gas, ammonia, and organic vapor. Record the data as directed in the work package.

E4. If the combustible gas level in the tank exceeds $25 \%$ of the LFL, disregard ammonia and organic vapor sampling and perform Steps D1 through D8.

E5. Repeat Steps E3 and E4 twice.

E6. Configure the assigned tank access point to the condition as specified in the work package.

\subsubsection{Sampling Through a Sampling Port (Tank 204-A R-TK-1)}

Catch tank 204-AR-TK-1 is actively ventilated by an exhauster. Headspace gas is swept by air, flows through a 3-inch diameter duct, and passes through a HEPA filter before being released to the atmosphere. Air flow through the duct is maintained at approximately 11 cubic feet per minute (cfm). At this air flow, it is expected that the combustible gas level in the duct is equal to that in the tank headspace. Thus, combustible gas level will be measured through a sampling port located on the exhaust duct. Also, installation of a temporary HEPA-type filter, if combustible gas level exceeds $25 \%$ of the LFL, would not be necessary since the tank is already ventilated. The direction for sampling through a sampling port is provided in Steps F1 through F6.

F1. Connect the sampling instrument to the designated sampling port as directed in the work package.

F2. Purge the sampling equipment with headspace gas using the CGM for the duration specified in the work package.

F3. Measure the concentrations of combustible gas, ammonia, and organic vapor. Record the data as directed in the work package.

F4. If the combustible gas level in the tank exceeds $25 \%$ of the LFL, disregard ammonia and organic vapor sampling and perform Steps D1 through D8.

F5. Repeat Steps F3 and F4 twice.

F6. Configure the assigned access point to the condition as specified in the work package. 


\section{HNF-4082 Rev. 4}

\subsection{RADIATION SCREENING}

Tritium traps and particulate air filter assemblies will be shipped by CPO to the Waste Sampling and Characterization Facility (WSCF) for analysis. The tritium traps will be analyzed for tritium; the air filters will be analyzed for total alpha, total beta, and gamma energy analyses. Radiation Protection will use the data to determine whether or not the SUMMA $^{\mathrm{TM}}$ samples can be radiologically released (and therefore can be accepted by the laboratory). CPO will store the SUMMA ${ }^{\mathrm{TM}}$ samples until they are released and will ship them to the laboratory at that time. 


\section{HNF-4082 Rev. 4}

\subsection{REFERENCES}

Bauer, R. E., 1998, Test Plan for Headspace Gas Concentration Measurements and Headspace Ventilation Rate Measurements for DCRTs 241-A-244, 241-BX-244, 241-S-244, and 24I-TX-244, HNF-2543, DE\&S Hanford, Inc., Richland, Washington.

Bauer, R. E. and Hedengren, D. C., 1999, Headspace Gas Concentration Measurements and Headspace Ventilation Rate Measurements for Double-Contained Receiver Tanks 241-A-244, 241-BX-244, 241-S-244, and 241-TX-244, HNF-2923, Rev. 0-A, DE\&S Hanford, Inc., Richland, Washington.

Bobrowski S. F. and C. H. Simonen, 1999, Standard Electronic Format Specification for Tank Vapor Data MSExcel Spreadsheets: Version 1.0, HNF-3815, Rev. 0, prepared by the Pacific Northwest National Laboratory for Lockheed Martin Hanford Corporation, Richland, Washington.

CHG 1999, Nonconforming Item Reporting and Control, RPP-PRO-298, Rev. 0, CH2Mhill Hanford Group, Inc., Richland, Washington.

DOE 1998, Hanford Analytical Services Quality Assurance Requirements Document, DOE/RL96-68, Rev. 2, U. S. Department of Energy, Richland Field Office, Richland, Washington.

Dukelow, G. T., J. W. Hunt, H. Babad, and J. E. Meacham, 1995, Tank Safety Screening Data Quality Objective, WHC-SD-WM-SP-004, Rev. 2, Westinghouse Hanford Company, Richland, Washington.

LMHC 1999, Tank Waste Remediation System Technical Safety Requirements, HNF-SDWM-TSR-006, Rev. 1-B, Lockheed Martin Hanford Corporation, Richland, Washington.

Meznarich, H. K., 1999, Waste Sampling and Characterization Facility Quality Assurance Program Plan, HNF-SD-CP-QAPP-017, Rev. 3, Waste Management Hanford, Inc., Richland, Washington.

PNNL 1999a, Quantitative Gas Mass Spectrometry, PNNL-98523-284, Rev. 0, Pacific Northwest National Laboratory, Richland, Washington.

PNNL 1999b, PNNL QA Program for Conducting Analytical Work in Support of Regulatory Programs, http://quality.pnl.gov/Guidance/QualityAssurancePlanning, Pacific Northwest National Laboratory, Richland, Washington.

Wilkins, N. E., and R. E. Bauer, 1996, Test Evaluation of Industrial Hygiene Hand Held Combustible Gas Monitor, WHC-SD-WM-TRP-256, Rev. 0, Westinghouse Hanford Company, Richland, Washington. 
HNF-4082 Rev. 4

This page intentionally left blank. 


\section{HNF-4082 Rev. 4}

\section{APPENDIX A}

\section{METHOD FOR CALCULATING VENTILATION RATE IN A CATCH TANK}


HNF-4082 Rev. 4

This page intentionally left blank 
HNF-4082 Rev. 4

METHOD FOR CALCULATING VENTILATION RATE IN A CATCH TANK

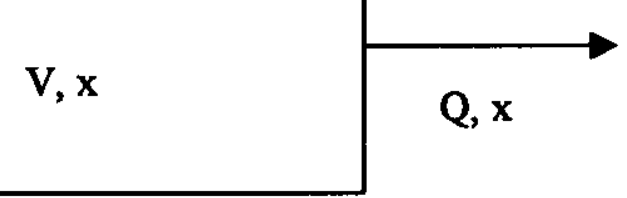

Where V: volume of headspace (volume of tank - volume of liquid)

$Q$ : ventilation rate

$\mathbf{x}$ : concentration of helium at any given time after gas injection

Mass balance for helium:

Rate of helium out - Rate of helium in $=$ Rate of helium loss

The rate of helium entering the tank after completion of gas injection can be considered negligible. The mass balance equation can be re-written as:

$$
\begin{array}{r}
Q x=-V \frac{d x}{d t} \\
\text { Or } \quad d t=\frac{-V}{Q} \frac{d x}{x}
\end{array}
$$

Integration of Equation (2) gives:

$$
\begin{aligned}
\int_{1}^{2} d t & =\frac{-V}{Q} \int_{1}^{2} \frac{d x}{x} \\
\Delta t & =\frac{-V}{Q}\left(\ln x_{2}-\ln x_{1}\right) \\
\Delta t & =\frac{V}{Q} \ln \frac{x_{1}}{x_{2}} \\
\text { Or } \quad Q & =\frac{V}{\Delta t} \ln \frac{x_{1}}{x_{2}}
\end{aligned}
$$

$\mathrm{x}_{1}$ and $\mathrm{x}_{2}$ will be determined from analysis of the SUMMA ${ }^{\mathrm{TM}}$ samples. $\Delta t$ is the time interval between collection of the two sample sets. 
Equation (3) can be re-written as follow for the period between gas injection and collection of the first set of SUMMA ${ }^{\mathrm{TM}}$ samples $\left(\Delta t_{0}\right)$ :

$$
Q=\frac{V}{\Delta t_{o}} \ln \frac{x_{o}}{x_{1}}
$$

$x_{0}$, the initial concentration of helium in the tank, can be estimated as follows:

Assume helium behaves as an ideal gas:

$$
\begin{aligned}
& \mathrm{PV}=\mathrm{nRT} \\
& n R=\frac{P_{c} V_{c}}{T_{c}}=\frac{P_{o} V_{o}}{T_{o}}
\end{aligned}
$$

Where $P_{c}, V_{c}$, and $T_{c}$ are pressure, volume, and temperature of helium in the gas cylinder and $P_{0}, V_{0}$, and $T_{0}$ are the same properties of helium in the catch tank immediately after injection.

Equation (5) can be re-arranged to:

$$
V_{o}=V_{c} \frac{P_{c}}{P_{o}} \frac{T_{o}}{T_{c}}
$$

The initial concentration of helium in the catch tank after completion of the gas injection is:

$$
x_{o}=\frac{V_{o}}{V}
$$

Three significant assumptions are associated with the calculation of $\mathrm{x}_{\mathbf{0}}$ : one, helium behaves like an ideal gas; two, ambient temperature is the same as that in the tank vapor space (This assumption is necessary because there are no temperature probes in the catch tanks); and three, the rate of helium loss during gas injection is negligible. Because of these assumptions, ventilation rates should be calculated based on data from analyses of the SUMMA ${ }^{\mathrm{TM}}$ samples. If necessary, calculation of the ventilation rate using helium gas bottle data will be performed for verification. 
HNF-4082 Rev. 4

APPENDIX B

DATA SHEET FOR USE WITH TRACER GAS INJECTION

B-1 
HNF-4082 Rev. 4

This page intentionally left blank.

B-2 
TRACER GAS INJECTION DATA SHEET

\section{Catch Tank Number:}

\begin{tabular}{|c|c|c|c|c|c|c|c|}
\hline \multirow{2}{*}{$\begin{array}{c}\text { Data } \\
\text { Description }\end{array}$} & \multirow[t]{2}{*}{ Sample No. } & \multirow[t]{2}{*}{ Date } & \multicolumn{2}{|c|}{ Time } & \multicolumn{2}{|c|}{ Pressure } & \multirow{2}{*}{$\begin{array}{c}\text { Recorded } \\
\text { By }\end{array}$} \\
\hline & & & Start & Stop & Start & Stop & \\
\hline Gas Injection & $\mathrm{NA}^{1}$ & & & & & & \\
\hline \multicolumn{2}{|c|}{$\begin{array}{ll}\text { Gas Cylinder } & \\
\text { Temperature: } & { }^{\circ} \mathrm{F}\end{array}$} & & & NA & NA & NA & \\
\hline \multicolumn{2}{|c|}{$\begin{array}{l}\text { Ambient Air } \\
\text { Temperature: } \quad{ }^{\circ} \mathrm{F}\end{array}$} & & & NA & NA & NA & \\
\hline \multirow{3}{*}{$\begin{array}{l}\text { Sample } \\
\text { Set } 1\end{array}$} & Canister 1 & & & & NA & NA & \\
\hline & $\#: V_{-}$ & & & & & & \\
\hline & \#: $\begin{array}{r}\text { Canister 2 } \\
\end{array}$ & & & & NA & NA & \\
\hline \multicolumn{2}{|c|}{$\begin{array}{ll}\text { Ambient Air } & \\
\text { Temperature: } & { }^{\circ} \mathrm{F}\end{array}$} & & & NA & NA & NA & \\
\hline \multirow{4}{*}{$\begin{array}{l}\text { Sample } \\
\text { Set } 2\end{array}$} & $\overline{\text { Canister } 1}$ & & & & $\mathrm{NA}$ & NA & \\
\hline & $\#: \mathrm{V} \_-\mathrm{B} 1-$ & & & & & & \\
\hline & Canister 2 & & & & NA & NA & \\
\hline & $\#: \mathbf{V}_{-}$ & & & & & & \\
\hline \multicolumn{2}{|c|}{$\begin{array}{l}\text { Ambient Air } \\
\text { Temperature: } \quad{ }^{\circ} \text { F }\end{array}$} & & & NA & NA & NA & \\
\hline \multirow{4}{*}{$\begin{array}{c}\text { Sample } \\
\text { Set } 3 \\
\text { (Optional) }\end{array}$} & Canister 1 & & & & NA & NA & \\
\hline & $\#: \mathrm{V}_{\longrightarrow} \quad-\mathrm{Cl}-$ & & & & & & \\
\hline & Canister 2 & & & & NA & NA & \\
\hline & $\#: V_{-}$ & & & & & & \\
\hline \multicolumn{2}{|c|}{$\begin{array}{ll}\text { Ambient Air } & \\
\text { Temperature: } & \end{array}$} & & & NA & NA & NA & \\
\hline
\end{tabular}

\section{Comments or Observations:}

\section{NA: Not Applicable}

Note: Temperature measurements should be performed during (or as close as possible to) the gas injection or sampling. 
HNF-4082 Rev. 4

This page intentionally left blank.

B-4 